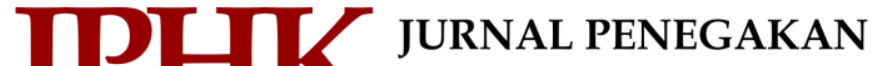 HUKUM DAN KEADILAN}

Vol. 2 No. 2, September 2021, Hal. 130-146

P-ISSN: 2746-0967, E-ISSN: 2721-656X
Gedung Pascasarjana Kampus Terpadu UMY Jalan Brawijaya, Tamantirto, Kasihan, Bantul, Yogyakarta 55183

Telepon : (0274) 387656 Ext. 346

Email : jphk@umy.ac.id

\title{
Mahkamah Konstitusi Indonesia di Era Digital: Upaya Menegakan Konstitusi, Keadilan Substantif dan Budaya Sadar Berkonstitusi
}

\section{Hani Adhani}

Ph.D. Candidate, Faculty of Law, International Islamic University Malaysia, Malaysia

E-mail:adhanihani@gmail.com

\section{INFO ARTIKEL \\ Perjalanan Artikel: \\ Artikel Dikirimkan oleh penulis: 16-05-21 \\ Artikel Direview: 10-06-21 \\ Artikel Direvisi: 09-11-21 \\ Artikel Diterima atau \\ Dipublikasikan: 15-11-21 \\ DOI: \\ 10.18196/jphk.v2i2.11763}

\begin{abstract}
ABSTRAK
Penelitian ini dilakukan untuk mengakji upaya Mahkamah Konstitusi sebagai lembaga peradilan baru yang bertugas menjaga konstitusi dan demokrasi serta melindungi hak asasi manusia agar dapat dengan mudah dikenali oleh masyarakat Indonesia melalui alat bantu teknologi digital sehingga masyarakat Indonesia bukan hanya dapat dengan mudah mengetahui Mahkamah Konstitusi namun juga dapat dengan mudah mengajukan permohonan atau gugatan ke Mahkamah Konstitusi apabila mengalami kerugian konstitusional. Dalam penelitian ini menggunakan data sekunder, yakni data yang diperoleh dari studi kepustakaan mulai UUD 1945, risalah amandemen UUD 1945, UU MK dan peraturan lainnya tentang $M K$, laporan tahunan $M K$, artikel, buku dan juga berbagai berita. Hasil dari penelitian ini dapat disimpulkan bahwa Mahkamah Konstitusi telah berhasil menjadi pengadilan konstitusi yang bukan hanya di percaya oleh masyarakat, namun juga menjadi benchmark dalam hal penggunaan teknologi E-Court yang memudahkan masyarakat untuk mengajukan gugatan ke Mahkanmah Konstitusi.
\end{abstract}

Kata Kunci: E-Court, era digital, Mahkamah Konstitusi, modern dan terpercaya, pengadilan modern, UUD 1945

\section{Pendahuluan}

Bangsa Indonesia sebagai salah satu negara yang memiliki jumlah penduduk terbesar di dunia baru mendeklarasikan kemerdekaannya pada tanggal 17 Agustus 1945. Kemerdekaan ini diperoleh Bangsa Indonesia setelah di jajah oleh Belanda selama 350 tahun dan Jepang selama 3,5 tahun. Kemerdekaan Bangsa Indonesia yang dideklarasikan pada tanggal 17 Agustus 1945 kemudian diperjelas dengan diundangkannya Konstitusi Indonesia yaitu Undang-Undang Dasar (UUD) 1945 pada tanggal 18 Agustus 1945.

UUD 1945 yang diundangkan pada tanggal 18 Agustus 1945 tersebut masih sangat sederhana yaitu hanya terdiri atas pembukaan, 16 bab dan 37 pasal. Dalam rapat pembahasan pembentukan Konstitusi Indonesia pada tahun 1945, ide pembentukan Mahkamah Konstitusi (MK) sebenarnya sudah ada, namun saat itu ide pembentukan MK memang belum menjadi isu penting, sehingga dalam UUD 1945 
sebelum amandemen, kekuasaan kehakiman hanya diserahkan kepada Mahkamah Agung (MA). Namun, terkait dengan isu kewenangan MK sudah ada dan dibahas dalam pembentukan awal UUD 1945. Salah satunya adalah usulan salah seorang perumus Konstitusi Indonesia yaitu Muhammad Yamin yang meminta untuk memasukan kewenangan menguji undang-undang kepada MA. Meskipun ide tersebut ditolak oleh Soepomo dengan alasan bahwa sistem Konstitusi Indonesia tidak menganut trias politica dan pada saat itu belum banyak para sarjana hukum. Pasca kemerdekaan, ide tentang pengujian undang-undang yang identik dengan kewenangan yang dimiliki oleh MK juga sempat diusulkan pada tahun 1970 oleh ikatan sarjana hukum agar MA diberikan kewenangan untuk menguji undangundang. Namun usulan tersebut juga tidak terlaksana. ${ }^{1}$

Setelah era reformasi tahun 1998, Majelis Permusyawaratan Rakyat (MPR) kemudian membuat ketetaapan MPR Nomor III/MPR/2000 tentang Sumber Hukum dan Tata Urutan Peraturan Perundang-undangan, dimana Pasal 5 ayat (1) menyatakan "MPR berwenang menguji undang-undang terhadap UUD 1945 dan Ketetapan MPR." Dalam pembahasan amandemen konstitusi yang dilakukan oleh badan pekerja MPR akhirnya disepakati tentang pembentukan lembaga kekuasaan kehakiman yang baru yang bernama Mahkamah Konstitusi. ${ }^{2}$

Dalam perkembangannya, MK yang lahir dari rahim reformasi berupaya untuk meyakinkan masyarakat bahwa pengadilan ini berbeda dengan pengadilan yang telah ada sebelumnya yakni MA. Ini terlihat dari upaya MK dalam hal membangun budaya dan manajemen pengadilan yang baru dengan penekanan pada putusan yang berkualitas dengan di dukung oleh Information and Communication Technology (ICT) yang sebenarnya sudah cukup lama di adopsi oleh pengadilan di negara lain. ${ }^{3}$ Dengan segala keterbatasan yang dimilikinya, MK yang berdiri sejak tahun 2003 pada akhirnya dapat menjelma menjadi pengadilan yang bukan hanya dapat di percaya karena putusan-putusannya yang substantif dan fenomenal namun lebih jauh menghadirkan E-Court di masyarakat sehingga masyarakat Indonesia dari Sabang sampai Merauke dapat dengan mudah mengakses MK tanpa perlu datang ke Jakarta. Hal tersebut pada akhirnya menjadi pencetus utama hadirnya kesadaran konstitusional masyarakat secara kolektif sehingga dapat membangun budaya sadar berkonstitusi.

\section{Metodologi}

Penelitian ini menggunakan data sekunder yang diperoleh dari studi kepustakaan seperti UUD 1945, risalah amandemen UUD 1945, UU MK, peraturan lain yang berkaitan dengan MK, laporan tahunan MK, artikel, buku dan berbagai

\footnotetext{
${ }^{1}$ Narasi ini sering disampaikan dalam slide power point Hakim Konstitusi saat sosialiasi ke berbagai daerah di Indonesia.

2 Silahkan lihat Naskah Komprehensif Perubahan UUD 1945 - Buku III Jilid I hal. 459

3 Beberapa negara yang telah mengembangkan E-Court diantaranya Mahkamah Konstitusi Korea, Mahkamah Agung Amerika Serikat, dan Mahkamah Konstitusi Jerman.
} 
pemberitaan terkait dengan MK. Teknik pengumpulan data dalam tulisan ini adalah studi literatur dan studi kasus. Studi literatur dilakukan dengan mempelajari risalah amandemen UUD 1945, sejarah MK, buku-buku, artikel, jurnal dan informasi yang berkaitan dengan MK. Studi kasus dilakukan dengan melihat fakta-fakta yang terjadi di lapangan sejak MK berdiri hingga saat ini khususnya terkait dengan berbagai putusan MK yang menjadi landmark dan penggunaan E-Court. Analisis data dilakukan dalam bentuk analisis kualitatif terhadap data yang menggambarkan mekanisme penyelesaian manajemen berperkara di MK yang berorientasi pada prinsip keadilan, kepastian hukum dan kemanfaatan bagi masyarakat.

\section{Analisis dan Hasil}

\subsection{Alasan Dibentuknya Mahkamah Konstitusi}

Ide pembentukan Mahkamah Konstitusi pada era reformasi mulai dikemukakan pada masa sidang kedua Panitia Ad Hoc I Badan Pekerja Majelis Permusyawaratan Rakyat (PAH I BP MPR) setelah seluruh anggota Badan Pekerja MPR melakukan studi banding ke 21 (dua puluh satu) negara mengenai konstitusi pada bulan Maret-April tahun 2000. Ide ini belum muncul pada saat perubahan pertama UUD 1945, bahkan belum ada satupun fraksi di MPR yang mengajukan usul itu. Nampaknya para anggota MPR sangat terpengaruh atas temuannya dalam studi banding tersebut. Walaupun demikian, pada sidang tahunan MPR bulan Agustus tahun 2000, rancangan rumusan mengenai Mahkamah Konstitusi masih berupa beberapa alternatif dan belum final. ${ }^{4}$

Pembahasan tentang pembentukan Mahkamah Konstitusi dimulai pada tahun 2001, yaitu pada saat perubahan ketiga UUD 1945. Beberapa hal baru dalam perubahan ketiga yakni penyempurnaan asas kedaulatan rakyat, impeachment Presiden dan/atau Wakil Presiden, pembentukan Dewan Perwakilan Daerah (DPD), pengaturan Pemilu, meneguhkan kedudukan Badan Pemeriksa Keuangan (BPK), membentuk lembaga baru Mahkamah Konstitusi dan Komisi Yudisial dalam bab kekuasaan kehakiman serta Pemilu Presiden/Wakil Presiden yang dilakukan secara langsung. ${ }^{5}$

Dibentuknya MK sebagai lembaga kekuasaan kehakiman baru dalam pembahasan amandemen konstitusi menjadi hal yang sangat penting, dimana kewenangan yang diberikan oleh UUD 1945 kepada MK begitu besar sehingga menjadi sangat penting dalam sistem ketatanegaraan Indonesia. ${ }^{6}$ Perdebatan tentang mengapa MK ini harus ada, menjadi bagian yang sangat penting dalam

4 Sutiyoso, B. (2010). Pembentukan Mahkamah Konstitusi Sebagai Pelaku Kekuasaan Kehakiman Di Indonesia. Jurnal Konstitusi, 7(6), 25-49.

${ }^{5}$ Lihat Naskah Komprehensif Perubahan UUD 1945 - Buku V hal. 110

6 Subiyanto, A. (2012). Mendesain Kewenangan Kekuasaan Kehakiman Setelah Perubahan UUD 1945. Jurnal Konstitusi, 9(4), 661-680. 
pembahasan amandemen ketiga UUD 1945 pada tahun 2001. Adapun dalam pembahasan tersebut Badan Pekerja Majelis Permusyawaratan Rakyat (BP MPR) memanggil beberapa ahli hukum untuk menjawab isu tentang pembentukan MK tersebut. $^{7}$

Adapun beberapa pendapat ahli hukum yang dihadirkan pada saat pembahasan amandemen UUD 1945 yang membahas secara khusus tentang MK adalah sebagai berikut:

Prof. Dr. Sri Soemantri Martosuwignyo ${ }^{8}$

Mengenai MK, ada dua alternatif. Pertama, terpisah dan tidak berada di bawah MA. Kedua, berada di bawah MA dan namanya diganti menjadi peradilan konstitusi.

Prof. Dr. Maria S.W. Sumarjono, S.H., MCL. ${ }^{9}$

Kewenangan MK dalam pengujian undang-undang (judicial review) supaya tuntas judicial review tidak sebatas pada pengujian undang-undang tetapi juga peraturan yang berada di bawahnya.

Prof. Jimly Asshidiqie ${ }^{10}$.

Menurur Jimly, MK menjadi sangat penting oleh karena adanya kasus impeachment Presiden Abdurahman Wahid yang tanpa melalui proses hukum. Presiden Abdurahman Wahid diberhentikan dalam jabatanya sebagai Presiden hanya melalui proses politik, hal tersebut dianggap sebagai sesuatu yang tidak adil oleh karena akan mengakibatkan pelemahan terhadap sistem Pemerintahan Presidensial.

Berdasarkan hasil pembahasan seluruh anggota Panitia Ad Hoc 1 Badan Pekerja MPR (PAH 1 BP MPR) dan pasca para anggota tersebut melakukan studi banding tentang konstitusi ke 21 negara akhirnya disepakati dibentuknya MK yang diatur secara khusus dalam UUD 1945 hasil amandemen yaitu di Pasal 24C, Bab IX tentang Kekuasaan Kehakiman.

Selengkapnya kewenangan MK yang diatur dalam Pasal 24C UUD 1945 adalah sebagai berikut: ${ }^{11}$

a. Mahkamah Konstitusi berwenang mengadili pada tingkat pertama dan terakhir yang putusannya bersifat final ${ }^{12}$ untuk menguji undang-undang terhadap UUD 1945, memutus sengketa kewenangan Lembaga negara yang kewenangannya

\footnotetext{
${ }^{7}$ Op cit, hal. 318

${ }^{8}$ Lihat Naskah Komprehensif Perubahan UUD 1945 - Buku VI

${ }^{9}$ Ibid hal. 666

10 Asshiddiqie, J. (2007). Pembentukan Mahkamah Konstitusi.

${ }^{11}$ Lihat UUD 1945 hasil amandemen Pasal 24C

12 Malik. (2009). Telaah Makna Hukum Putusan Mahkamah Konstitusi yang Final dan Mengikat. Jurnal Konstitusi, 6(1), 79-104.
} 
diberikan oleh UUD 1945, memutus pembubaran partai politik, dan memutus perselisihan tentang hasil pemilihan umum.

b. Mahkamah Konstitusi wajib memberikan putusan atas pendapat Dewan Perwakilan Rakyat mengenai dugaan pelanggaran oleh Presiden dan/atau Wakil Presiden menurut Konstitusi.

c. Mahkamah Konstitusi mempunyai sembilan orang anggota hakim konstitusi yang ditetapkan oleh Presiden, yang diajukan masing-masing tiga orang oleh Mahkamah Agung, tiga orang oleh Dewan Perwakilan Rakyat, dan tiga orang oleh Presiden.

d. Ketua dan Wakil Ketua Mahkamah Konstitusi dipilih dari dan oleh hakim konstitusi.

e. Hakim konstitusi harus memiliki integritas dan kepribadian yang tidak tercela, adil, negarawan yang menguasai konstitusi dan ketatanegaraan, serta tidak merangkap sebagai pejabat negara.

f. Pengangkatan dan pemberhentian hakim konstitusi, hukum acara serta ketentuan lainnya tentang Mahkamah Konstitusi diatur dengan undangundang.

Pasca diaturnya MK dalam Pasal 24C UUD 1945, kemudian disepakati bahwa harus ada aturan peralihan yang cukup komprehensif sehingga UUD 1945 hasil amandemen dapat digunakan sebagai landasan konstitusional dalam praktik ketatanegaraan termasuk yang mencakup keberadaan lembaga baru seperti Mahkamah Konstitusi dan Komisi Yudisial. ${ }^{13}$

\subsection{Undang-Undang MK dan Pembentukan Mahkamah Konstitusi}

Sebagai upaya untuk mempercepat terbentuknya Mahkamah Konstitusi, maka Dewan Perwakilan Rakyat (DPR) kemudian melakukan berbagai acara seminar dan kajian ilmiah sebagai upaya untuk mempercepat proses pembentukan Undang-Undang Mahkamah Konstitusi (UU MK). Dengan batas waktu pembentukan MK sebagaimana diatur dalam aturan peralihan konstitusi yaitu pada tanggal 17 Agustus 2003, maka pembahasan UU MK dilakukan secara cepat.

Akhirnya pada tanggal 13 Agustus 2003,14 diundangkan UU MK dan setelah itu tiga lembaga yang diatur dalam konstitusi yaitu Presiden, Dewan Perwakilan Rakyat (DPR) dan MA melakukan rekrutmen untuk memilih masing-masing tiga calon hakim konstitusi. Dari hasil proses rekrutmen ketiga lembaga tersebut

\footnotetext{
${ }^{13}$ Lihat Naskah Komprehensif Perubahan UUD 1945 - Buku VI, Sekretariat Jenderal dan Kepaniteraan Mahkamah Konstitusi, 2010, hal. 14

14 Putri, N. A. (2015). Implikasi Putusan Mahkamah Konstitusi Terkait Dengan Penambahan Norma Penetapan Tersangka Sebagai Objel Praperadilan. Universitas Islam Negeri Syarif Hidayatullah.
} 
terpilihlah sembilan hakim konstitusi pertama. Adapun nama-nama hakim tersebut dapat dilihat pada Tabel $1 .{ }^{15}$

Tabel 1. Sembilan Hakim Konstitusi Pertama

\begin{tabular}{|l|l|l|}
\hline No. & \multicolumn{1}{|c|}{ NAMA } & \multicolumn{1}{|c|}{ LEMBAGA } \\
\hline 1. & Prof. Dr. M. Laica Marzuki, SH & Mahkamah Agung \\
\hline 2. & Maruarar Siahaan, SH. & Mahkamah Agung \\
\hline 3. & Soedarsono, SH. & Mahkamah Agung \\
\hline 4. & Prof. Jimly Asshidiqie & Dewan Perwakilan Rakyat \\
\hline 5. & Letjend. (purn) Achmad Roestandi, SH. & Dewan Perwakilan Rakyat \\
\hline 6. & I Dewa Gede Palguna, SH., MH. & Dewan Perwakilan Rakyat \\
\hline 7. & Prof. Abdul Mukthie Fadjar, SH., MS. & Presiden \\
\hline 8. & Dr. Harjono, SH., MCL. & Presiden \\
\hline 9. & Prof. Dr. Ahmad Syarifuddin Natabaya, SH., LLM. & Presiden \\
\hline
\end{tabular}

Pelantikan sembilan Hakim Mahkamah Konstitusi pertama dilaksanakan pada tanggal 16 Agustus 2003 oleh Presiden Megawati Soekarnoputri.

\subsubsection{Pemilihan Ketua dan Wakil Ketua Mahkamah Konstitusi}

Tepat tiga hari setelah pelantikan sembilan hakim konstitusi, bertempat di Gedung Mahkamah Agung pada tanggal 19 Agustus 2003, kemudian dilakukan pemilihan Ketua dan Wakil Ketua Mahkamah Konstitusi oleh sembilan hakim konstitusi. Sebagaimana diatur dalam UU MK bahwa pemilihan Ketua dan Wakil Ketua MK dipimpin oleh hakim yang paling tua usianya sehingga pada saat pemilihan Ketua dan Wakil Ketua Mahkamah Konstitusi maka yang memimpin jalannya rapat atau sidang pemilihan Ketua dan Wakil Ketua Mahkamah Konstitusi adalah Letjend Achmad Roestandi. Dalam pemilihan tersebut terpilih Jimly Asshidiqie sebagai Ketua dan Laica Marzuki sebagai Wakil Ketua. Kedua hakim terpilih tersebut kemudian dilantik di hadapan 7 (tujuh) hakim konstitusi dan mengucapkan sumpah jabatan sebagai Ketua dan Wakil Ketua Mahkamah Konstitusi pertama. ${ }^{16}$

\subsubsection{Pelimpahan Perkara dari Mahkamah Agung ke Mahkamah Konstitusi}

Setelah terpilih Ketua dan Wakil Ketua MK, maka selanjutnya pada tanggal 15 Oktober 2003 bertempat di Gedung Mahkamah Agung, Ketua Mahkamah Agung saat itu yaitu Prof. Bagir Manan menyerahkan perkara pengujian undang-undang dari MA ke MK yang diterima oleh Ketua MK Prof. Jimly Asshiddiqie. Adapun jumlah perkara pengujian undang-undang yang diserahkan dari MA ke MK seperti pada Table 2.

\footnotetext{
${ }^{15}$ Nama dan profil hakim bisa di cek di website MK, http://www.mkri.id

16 Lihat Laporan Tahunan Mahkamah Konstitusi Tahun 2003, Sekretariat Jenderal dan Kepaniteraan Mahkamah Konstitusi, 2003, hal. 26.
} 
Tabel 2. Jumlah Perkara Pengujian Undang-Undang yang Diserahkan dari MA ke MK

\begin{tabular}{|c|c|c|}
\hline No. & Perkara & Perihal \\
\hline 1. & 001/PUU-I/ 2003 & $\begin{array}{lllllll}\text { Pengujian Undang-Undang Nomor } & 20 & \text { Tahun } & 2002 & \text { tentang } \\
\text { Ketenagalistrikan }\end{array}$ \\
\hline 2. & 002/PUU-I/ 2003 & $\begin{array}{l}\text { Pengujian Undang-Undang Nomor } 22 \text { Tahun } 2001 \text { tentang Minyak } \\
\text { dan Gas Bumi }\end{array}$ \\
\hline 3. & 003/PUU-I/ 2003 & $\begin{array}{l}\text { Pengujian Undang-Undang Nomor } 24 \text { Tahun } 2002 \text { tentang Surat } \\
\text { Utang Negara }\end{array}$ \\
\hline 4. & 004/PUU-I/ 2003 & $\begin{array}{llllll}\text { Pengujian Undang-Undang } & \text { Nomor } & 14 & \text { Tahun } & 1985 & \text { tentang } \\
\text { Mahkamah Agung } & & & & & \end{array}$ \\
\hline 5. & 005/PUU-I/2003 & $\begin{array}{lllllll}\begin{array}{l}\text { Pengujian } \\
\text { Penyiaran }\end{array} & \text { Undang-Undang } & \text { Nomor } & 32 & \text { Tahun } & 2002 & \text { tentang } \\
\end{array}$ \\
\hline 6. & 006/PUU-I/2003 & $\begin{array}{l}\text { Pengujian Undang-Undang Nomor } 30 \text { Tahun } 2002 \text { tentang Komisi } \\
\text { Pemberantasan Tindak Pidana Korupsi }\end{array}$ \\
\hline 7. & 007/PUU-I/ 2003 & $\begin{array}{l}\text { Pengujian Undang-Undang Nomor } 12 \text { Tahun } 2003 \text { tentang } \\
\text { Pemilihan Umum Anggota Dewan Perwakilan Rakyat, Dewan } \\
\text { Perwakilan Daerah dan Dewan Perwakilan Rakyat Daerah. }\end{array}$ \\
\hline 8. & 008/PUU-I/2003 & $\begin{array}{l}\text { Pengujian Undang-Undang Nomor } 31 \text { Tahun } 2002 \text { tentang Partai } \\
\text { Politik. }\end{array}$ \\
\hline 9. & 009/PUU-I/2003 & $\begin{array}{llllll}\text { Pengujian Undang-Undang } & \text { Nomor } & 22 & \text { Tahun } & 1999 & \text { tentang } \\
\text { Pemerintahan Daerah. }\end{array}$ \\
\hline 10. & 010/PUU-I/ 2003 & $\begin{array}{l}\text { Pengujian Undang-Undang Nomor } 11 \text { Tahun } 2003 \text { tentang } \\
\text { Perubahan atas Undang-Undang Nomor } 53 \text { Tahun } 1999 \text { tentang } \\
\text { Pembentukan Kabupaten Pelalawan, Kabupaten Rokan Hulu, } \\
\text { Kabupaten Rokan Hilir, Kabupaten Siak, Kabupaten Karimun, } \\
\text { Kabupaten Natuna, Kabupaten Kuantan Singingi, dan Kota Batam. }\end{array}$ \\
\hline 11. & 011/PUU-I/2003 & $\begin{array}{l}\text { Pengujian Undang-Undang Nomor } 12 \text { Tahun } 2003 \text { tentang } \\
\text { Pemilihan Umum Anggota Dewan Perwakilan Rakyat, Dewan } \\
\text { Perwakilan Daerah dan Dewan Perwakilan Rakyat Daerah. }\end{array}$ \\
\hline 12. & 012/PUU-I/2003 & $\begin{array}{llllll}\text { Pengujian Undang-Undang } & \text { Nomor } & 13 & \text { Tahun } & 2003 & \text { tentang } \\
\text { Ketenagakerjaan. }\end{array}$ \\
\hline 13. & 013/PUU-I/2003 & $\begin{array}{l}\text { Pengujian Undang-Undang Nomor } 16 \text { Tahun } 2003 \text { tentang } \\
\text { Penetapan Peraturan Pemerintah Pengganti Undang-Undang Nomor } \\
2 \text { Tahun } 2002 \text { tentang Pemberantasan Tindak Pidana Terorisme. }\end{array}$ \\
\hline 14. & 014/PUU-I/ 2003 & $\begin{array}{l}\text { Pengujian Undang-Undang Susduk Majelis Permusyawaratan } \\
\text { Rakyat, Dewan Perwakilan Rakyat, Dewan Perwakilan Daerah dan } \\
\text { Dewan Perwakilan Rakyat Daerah. }\end{array}$ \\
\hline
\end{tabular}

\subsubsection{Penyiapan Suprastruktur dan Infrastruktur Mahkamah Konstitusi}

Pada saat awal pembentukan MK, infrastruktur dan suprastruktur belum sepenuhnya ada sehingga Ketua MK saat itu Prof. Jimly Asshidiqie harus berkoordinasi dengan sekretaris negara untuk menyiapkan infrastruktur dan suprastruktur Mahkamah Konstitusi mulai dari gedung untuk berkantor, ruang sidang, hingga pegawai.

Untuk membantu MK dalam menjalankan tugasnya, ditugaskanlah pejabat sementara Sekretaris Jenderal yaitu Janedjri M. Gaffar yang sebelumnya menjabat sebagai Kepala Biro Persidangan MPR sebagai penanggung jawab administrasi umum sedangkan untuk penanggung jawab administrasi yustisial ditugaskan 
Marcel Buchori dan Ahmad Fadlil Sumadi sebagai Panitera dan Wakil Panitera dari MA.

Untuk membantu kinerja MK, kemudian sekretaris jenderal melakukan rekrutmen pegawai MK yang berjumlah 82 orang. Jumlah Pegawai Mahkamah Konstitusi tersebut terdiri dari staf aahli, staf sekretaris jenderal dan staf kepaniteraan. Sedangkan untuk jabatan struktural yang harus berstatus sebagai Pegawai Negeri Sipil (PNS) seperti kepala bagian dan jabatan panitera pengganti, ditugaskan dari sekretariat MPR dan MA.

Selain pegawai yang merupakan bagian dari suprastruktur, MK juga membutuhkan infrastruktur untuk mendukung kinerjanya khususnya gedung kantor dan juga gedung untuk bersidang. Untuk gedung kantor, pada tahap awal Mahkamah Konstitusi sempat berkantor di Hotel Santika Jakarta yang kemudian menyewa gedung perkantoran di wilayah Jakarta Selatan yang bernama Gedung Centris. ${ }^{17}$ Hakim dan seluruh staf Mahkamah Konstitusi berkantor di Gedung Centris dan pada saat itu MK hanya menyewa dua lantai gedung saja yaitu lantai untuk ruang kerja hakim dan lantai untuk kerja staf. Sedangkan untuk ruang gedung sidang, MK saat itu meminjam Gedung Nusantara IV MPR yang dijadikan sebagai ruang sidang sementara. ${ }^{18}$

\subsubsection{Sidang Pertama Mahkamah Konstitusi dan Putusan Pertama}

Setelah semua suprastruktur dan infrastruktur MK siap, maka tahapan selanjutnya adalah melaksanakan persidangan terhadap 14 perkara pengujian undang-undang yang merupakan pelimpahan dari MA.

Sidang pertama MK dengan agenda pemeriksaan pendahuluan untuk 14 perkara tersebut dilaksanakan di Gedung Nusantara IV MPR pada tanggal 4 November 2003. Persidangan dengan agenda pemeriksaan pendahuluan dilakukan secara cepat dengan model sidang pleno dimana sembilan hakim hadir dan memberikan masukan atau nasehat kepada Pemohon. Menurut Jimly Asshidiqie, dalam persidangan perdana MK tersebut akan secara marathon yakni dilakukan selama tiga hari dengan agenda utama persidangan yakni pemeriksaan pendahuluan. Selain itu menurut Jimly, dari 14 permohonan yang sudah ada selanjutnya akan dibagi masing-masing menjadi lima perkara tiap harinya untuk memeriksa permohonan tersebut. ${ }^{19}$

Meski sidang pertama MK dilaksanakan pada tangga 4 November 2003, namun MK berupaya untuk menyelesaikan gugatan konstitusional tersebut secara

17 Ibid hal. 15

18 Ibid hal. 17

19 Amr. (2003). Pemeriksaan Pendahuluan Mahkamah Konstitusi Dimulai Pekan Depan. hukumonline.com. Dikutip dari https://www.hukumonline.com/berita/baca/hol9037/pemeriksaanpendahuluan-mahkamah-konstitusi-dimulai-pekan-depan 
cepat. Filosofi "justice delay justice denied" yang diterapkan oleh Ketua MK Jimly Asshidiqie menyebabkan Mahkamah Konstitusi seperti berupaya untuk menyelesaikan semua perkara pengujian undang-undang yang masuk ke MK secara cepat. ${ }^{20}$

Salah satu putusan Mahkamah Konstitusi yang menjadi landmark pada saat awal MK berdiri adalah putusan perkara nomor 001/PUU-I/2003 tentang pengujian Undang-Undang Ketenagalistrikan. Putusan tersebut merupakan putusan pertama MK yang membatalkan seluruh Undang-Undang Ketenagalistrikan dengan nomor registrasi perkara pertama yang diterima oleh Mahkamah Konstitusi. ${ }^{21}$ Putusan tersebut menjadi putusan yang sangat bersejarah dan menjadi landmark oleh karena putusan tersebut diputuskan dengan sangat cepat dan semua Undang-Undang Ketenagalistrikan dibatalkan dengan pertimbangan yang sangat komprehensif dan mudah dimengerti oleh seluruh masyarakat.

\subsection{Upaya Makamah Konstitusi Mewujudkan Pengadilan yang Modern dan Terpercaya}

MK sebagai lembaga baru hasil amandemen UUD 1945 sejak berdiri tanggal 13 Agustus 2003 memang dalam perkembangannya belum begitu dikenal oleh masyarakat Indonesia sehingga diperlukan upaya untuk mensosialisasikan MK ke seluruh wilayah Indonesia. Upaya mensosialisasikan MK tersebut tentunya berjalan beriringan dengan mensosialisasikan UUD 1945 hasil amandemen kepada seluruh lapisan masyarakat agar mereka memahami benar perubahan apa saja yang ada dalam UUD 1945 hasil amandemen khususnya terkait dengan hak konstitusional warga negara yang diatur lebih rigid dalam amandemen UUD 1945.

Dengan jumlah penduduk Indonesia yang mencapai 260 juta jiwa dan tersebar di berbagai pulau yang berjumlah 17.000 pulau, maka mensosialisasikan UUD 1945 dan MK kepada seluruh rakyat Indonesia tidak dapat dikerjakan secara manual. Meski sejak MK berdiri hampir setiap bulan Hakim MK dan juga pegawai Mahkamah Konstitusi berkunjung ke seluruh provinsi di Indonesia untuk mensosialisasikan UUD 1945 hasil amandemen dan mensosialisasikan MK, namun hal tersebut masih tetap saja di rasa belum cukup sehingga diperlukan upaya lain untuk mensosialisasikan UUD 1945 dan mengenalkan MK ke seluruh warga Indonesia yang berada di 34 provinsi agar masyarakat dapat memahami benar apa itu MK dan hak konstitusional warga negara apa saja yang diatur dalam amandemen UUD 1945 sehingga pada akhirnya akan terbangun budaaya sadar berkonstitusi.

Ketua MK saat itu Jimly Asshidiqie dengan dibantu Sekretaris Jenderal Janedjri M. Gaffar berupaya untuk mencari jalan keluar agar UUD 1945 hasil amandemen dan

20 Amr. (2003). Pemeriksaan Pendahuluan Mahkamah Konstitusi Dimulai Pekan Depan. hukumonline.com. Dikutip dari https://www.hukumonline.com/berita/baca/hol9037/pemeriksaanpendahuluan-mahkamah-konstitusi-dimulai-pekan-depan.

21 Gie. (2004). MK Batalkan Keberlakuan UU Ketenagalistrikan. hukumonline.com. Dikutip dari https://www.hukumonline.com/berita/baca/hol11758/mk-batalkan-keberlakuan-uu-ketenagalistrikan 
MK dapat dengan mudah dikenal oleh masyarakat Indonesia. Tentunya salah satu indikator bahwa masyarakat memahami hasil amandemen UUD 1945 dan mengenal MK adalah dengan semakin banyaknya perkara atau permohonan konstitusional yang masuk ke MK. Dengan semakin banyaknya masyarakat mengetahui dan memahami amandemen UUD 1945 maka secara otomatis masyarakat juga akan dengan mudah memahami kewenangan MK. Terlebih lagi dengan semakin banyaknya putusan MK yang mengangkat isu-isu konstitusional warga negara sehingga MK telah menjelma menjadi pengadilan konstitusional yang memberikan rasa keadilan yang substantial bagi masyarakat Indonesia. Hal tersebut semakin menambah kepercayaan masyarakat terhadap MK. Tambah lagi, dengan adanya kemudahan akses bagi masyarakat dalam hal mendapatkan putusan yang hanya dengan mengklik putusan MK di website MK juga menjadi salah satu indikator dalam hal menilai tingkat kepatuhan masyarakat dan aparatur negara terhadap putusan $\mathrm{MK} .{ }^{22} \mathrm{Hal}$ tersebut semakin menandakan bahwa masyarakat secara keseluruhan telah sadar akan pentingnya hak konstitusional mereka yang dilindungi oleh UUD $1945 .^{23}$

Salah satu satu upaya MK untuk memudahkan masyarakat memahami amandemen UUD 1945 dan mengenal kewenangan MK adalah dengan membangun suatu sistem peradilan yang mudah di akses dan transparan ${ }^{24}$. Ketua MK pertama yaitu Jimly Asshidiqie berupaya untuk mewujudkan hal tersebut dengan menerapkan sistem E-Court di MK sehingga seluruh masyarakat dapat dengan mudah mengakses MK dan dapat dengan mudah dapat mengajukan perkara ke MK serta dapat memantau perkara mereka secara online. Hal tersebut merupakan bagian dari upaya untuk mewujudkan misi MK sebagai lembaga peradilan yang modern dan terpercaya. ${ }^{25}$

Untuk mewujudkan misi tersebut, MK melakukan berbagai inovasi melalui beberapa program dan media online dengan menggunakan ICT sebagai ikhtiar untuk mewujudkan peradilan MK yang modern dan terpercaya.

Berikut adalah beberapa program dan media yang telah dibangun oleh MK untuk mewujudkan peradilan MK yang modern dan terpercaya:

\subsubsection{Membangun Website Mahkamah Konstitusi}

Sebagai salah satu upaya untuk mewujudkan transparansi dan akuntabilitas lembaga peradilan MK yang diperintahkan oleh UU MK yakni dengan membangun website resmi MK. Website MK mulai di launching pasca sidang pertama MK tepatnya tanggal 4 November 2003 dengan berita pertama adalah tentang sidang pertama

\footnotetext{
${ }^{22}$ Badan Pembina Hukum Nasional. (2017). Rancangan Undang-Undang Kementerian Hukum Dan Hak Asasi Manusia.

23 Prasidi, D. (2010). Akses Publik Terhadap Informasi Di Pengadilan. Jurnal Konstitusi, 7(3), 161-184.

24 National Center for State Courts. (2013). The International Framework for Court Excellence. Dikutip dari https://www.courtexcellence.com/_data/assets/pdf_file/0013/7312/the-international-framework2e-2014-v3.pdf.

25 Sumadi, A. (2011). Independensi Mahkamah Konstitusi. Jurnal Konstitusi, 8(5), 631-648.
} 
perkara Undang-Undang Ketenagalistrikan. Saat itu oleh karena Gedung Perkantoran MK masih menyewa di Gedung Centris maka server website MK juga masih meminjam dan barulah pada saat Gedung MK berpindah dari Plaza Centris ke Jalan Medan Merdeka Barat Nomor 7 pada tanggal 22 Maret 2004 website MK memiliki server sendiri. Adapun nama lengkap website Mahkamah Konstitusi saat itu adalah www.mahkamahkonstitusi.go.id. ${ }^{26}$

Dalam tahap awal pembentukan, website MK hanya berisi konten tentang sejarah dan susunan hakim Mahkamah Konstitusi, Profil Hakim Mahkamah Konstitusi, jadwal sidang, risalah sidang dan info kegiatan MK. Kini setelah MK berdiri 18 tahun, website Mahkamah Konstitusi menjadi salah satu website terbaik lembaga negara di Indonesia karena menampilkan informasi yang up to date bagi masyarakat dan pencari keadilan. Kini website MK bukan hanya berisi tentang profil hakim dan risalah sidang, namun website MK sudah menjelma menjadi website yang ramah bagi masyarakat dan pencari keadilan.

Beberapa keunggulan website MK tersebut adalah: ${ }^{27}$

a. Menampilan informasi tentang jadwal sidang.

b. Menampilkan risalah sidang.

c. Menampilkan putusan.

d. Menampilkan berbagai peraturan perundangan-undangan.

e. Video Streaming.

f. Permohonan Online

g. Case managemen system.

h. Case tracking system.

i. Case retrival system.

j. Informasi good governance dan reformasi birokrasi.

k. Laporan tahunan,

dan banyak informasi lainnya yang memudahkan masyarakat untuk dapat mengakses segala hal terkait dengan Mahkamah Konstitusi.

\subsubsection{Court Recording System}

Salah satu yang menjadi pembeda antara MK dengan pengadilan lainnya di Indonesia adalah adanya risalah sidang yang dapat diakses oleh seluruh masyarakat melalui website MK baik dalam bentuk video, suara, maupun file pdf.

Risalah sidang ini menurut Sekretaris Jenderal Janedjri M. Gaffar adalah sebagai bentuk transparansi lembaga peradilan kepada masyarakat. Format risalah sidang ini mengikuti format risalah sidang MPR pada saat pembahasan amandemen UUD 1945. Sistem yang dikembangkan oleh MK saat ini mampu merekam seluruh

\footnotetext{
${ }^{26}$ Laporan Tahunan Mahkamah Konstitusi Tahun 2003, op.cit, hal. 66

27 Mahkamah Konstitusi Republik Indonesia. (2019). Home | The Constitutional Court of the Republic Indonesia. Dikutip dari mkri.id website: https://www.mkri.id/index.php?page=web.Beranda\&menu=1.
} 
proses persidangan dalam bentuk audio, video dan menyimpannya dalam bentuk digital dan transkripsi yang siap cetak. ${ }^{28}$

Dengan adanya risalah sidang tersebut maka semua fakta yang ada dalam persidangan dapat dibaca oleh para pihak dan masyarakat sehingga MK juga dapat dengan mudah untuk membuat putusan yang benar-benar adil dan transparan. ${ }^{29}$ Selain itu, dalam pembuatan risalah sidang tersebut, Mahkamah Konstitusi juga telah menggunakan sistem e-perisalah merupakan sebuah sistem solusi pembuat risalah dengan menggunakan teknologi pengenal wicara yang secara otomatis akan mentranskripsi semua ucapan baik dalam sidang maupun pertemuan. E-Perisalah memiliki fitur menampilkan ucapan pembicara, sehingga mudah dikenali kapan mulai bicara, siapa yang bicara, dan apa yang dibicarakan. Alat e-perisalah tersebut dikembangkan oleh Badan Pengkajian dan Penerapan Teknologi (BPPT) dan alasan BPPT memilih MK sebagai tempat pertama penerapan e-Perisalah karena BPPT menilai MK sebagai lembaga negara yang membuat transkrip terbaik di Indonesia saat ini. $^{30}$

\subsubsection{Video Conference}

Adanya fakta bahwa wilayah Indonesia sangat luas dan berbentuk kepulauan pada akhirnya menyebabkan adanya kesulitan bagi masyarakat untuk datang ke Gedung MK yang berada di ibukota negara yaitu Jakarta. Undang-Undang MK menyebutkan bahwa MK hanya berada di Jakarta sehingga tidak memungkinkan untuk membuka cabang di tiap provinsi di seluruh Indonesia.

Hal tersebut menyebabkan masyarakat Indonesia khususnya para pencari keadilan di seluruh wilayah Indonesia akan kesulitan untuk datang ke MK khusunya bagi masyarakat yang secara finansial tidak mampu. Oleh karena itu, untuk mengantisipasi permasalahan tersebut MK pada tanggal 20 Juni 2008 akhirnya bekerja sama dengan perguruan tinggi di 34 provinsi melakukan kerjasama untuk membuat alat bantu persidangan yang bernama Video Conference. ${ }^{31}$

Pengadaan video conference ini khususnya ditujukan bagi masyarakat yang memang sulit untuk datang ke Jakarta pada saat pelaksanaan sidang di MK. Mahkamah Konstitusi sebagai lembaga negara penjaga konstitusi dan penjaga hak asasi masyarakat berupaya untuk menjadikan video conference ini sebagai media tanpa batas sehingga masyarakat diseluruh wilayah Indonesia tetap dapat mengajukan sidang dan berperkara di MK meski mereka tidak datang ke Jakarta. Hal lain yang dapat dimanfaatkan dengan adanya video conference ini diharapkan agar para mahasiswa di perguruan tinggi di seluruh Indonesia juga dapat memanfaatkan video

28 Lihat Laporan Tahunan Mahkamah Konstitusi Tahun 2009, Sekretariat Jenderal dan Kepaniteraan Mahkamah Konstitusi, 2009, hal. 339.

29 Prasidi, D. (2010). Akses Publik Terhadap Informasi Di Pengadilan. Jurnal Konstitusi, 7(3), 161-184.

${ }^{30}$ Lihat Laporan Tahunan Mahkamah Konstitusi Tahun 2012, Sekretariat Jenderal dan Kepaniteraan Mahkamah Konstitusi, 2012 hal. 9.

31 Lihat Laporan Tahunan Mahkamah Konstitusi Tahun 2009 hal.339 
conference untuk berbagai kegiatan ilmiah seperti kegiatan kuliah jarak jauh atau bimbingan karya ilmiah jarak jauh dan berbagai acara ilmiah lainnya. ${ }^{32}$

Selain itu, oleh karena MK diberikan kewenangan untuk mengadili perkara sengketa pemilihan umum dan Pilkada, maka kebutuhan akan proses peradilan yang cepat (speedy trial) semakin meningkat saat MK menyidangkan perkara sengketa hasil pemilihan umum dan Pilkada. Untuk memenuhi kebutuhan itu, MK memperkenalkan penggunaan video conference. Video conference sangat berguna membuka aksesibilitas masyarakat terhadap sidang MK tanpa hadir secara fisik di Gedung MK di Jakarta sehingga membantu masyarakat di seluruh Indonesia. ${ }^{33}$

\subsubsection{Case Retrivel System}

Case retrival system adalah sebuah sistem yang dibangun di dalam website MK yang berfungsi sebagai mesin pencari informasi perkara. Sistem ini dibangun dengan bekerja sama dengan mesin pencari Google. Dalam sistem ini masyarakat dapat mengakses segala informasi tentang perkara di MK hanya dengan mengetik kata kunci yang dalam sistem tersebut. ${ }^{34}$

Sistem ini sebagai salah satu upaya MK untuk meyakinkan masyarakat bahwa peradilan Mahkamah Konstitusi sangat transparan dan mudah diakses khususnya terkait kemudahan mencari informasi tentang perkara yang sedang diadili oleh MK.

\subsubsection{Case Management System}

Case Management Sistem adalah informasi yang di desain untuk penanganan perkara di MK mulai dari pemberian informasi tentang prosedur beracara, penyampaian permohonan secara online, dan penyediaan informasi yang selalu di update tentang perkembangan perkara, jadwal sidang, risalah sidang, dan putusan.

Dengan demikian masyarakat dapat dengan mudah memperoleh informasi secara cepat dan tepat sehingga dapat mengikuti seluruh proses perkara. Case Management system ini mulai dipergunakan secara maksimal sejak tanggal 11 Agustus $2006 .{ }^{35}$ Dengan sistem ini seluruh masyaraakat dapat melakukan pendaftaran perkara ke Mahkamah Konstitusi secara online dengan tanpa dipungut biaya. Diharapkan dengan adanya Case Management System ini, masyarakat Indonesia dapat dengan mudah mengajukan permohonan ke MK sehingga acces to justice akan terbuka secara lebar serta dapat membangun prinsip semangat efisiensi sehingga penyelenggaraan peradilan yang murah, cepat dan sederhana dapat terwujud di Mahkamah Konstitusi. $^{36}$

\footnotetext{
32 Ibid hal. 340

33 Lihat Laporan Tahunan Mahkamah Konstitusi Tahun 2012 hal. 48

34 Ibid hal. 59

35 Lihat Laporan Tahunan Mahkamah Konstitusi Tahuan 2010, Sekretariat Jenderal dan Kepaniteraan Mahkamah Konstitusi, 2010, hal. 44

36 Lihat Laporan Tahunan Mahkamah Konstitusi Tahun 2008, Sekretariat Jenderal dan Kepaniteraan Mahkamah Konstitusi, 2008, hal. 338
} 
Untuk mengatur dan memperlancar pelaksanaan Case Management Sistem, Mahkamah Konstitusi menerbitkan Peraturan Mahkamah Konstitusi (PMK) Nomor 18 Tahun 2009 tentang Pedoman Pengajuan Permohonan Elektronik (Electronic Filling) dan Pemeriksaan Persidangan Jarak Jauh (video conference). ${ }^{37}$

\subsubsection{E-Kios Mahkamah Konstitusi}

E-Kios MK adalah suatu bentuk fasilitas digital yang disiapkan sebagai media untuk membantu masyarakat yang datang ke Gedung MK dengan tujuan untuk mengakses berbagai fitur-fitur penting terkait dengan kewenangan MK dan info persidangan sehingga diharapkan masyarakat dapat lebih merasakan manfaat nyata dari layanan prima yang disiapkan oleh MK pada saat datang ke Gedung MK.

Bentuk user-interface dari E-Kios MK berupa layar sentuh berukuran 42 inchi yang dilengkapi berbagai menu-menu yang dapat dengan leluasa diakses oleh masyarakat yang datang ke Gedung MK. Fitur-fitur yang ada pada E-Kios yang dapat diakses oleh masyarakat antara lain: website Mahkamah Konstitusi, live sidang, akses ke file-file multimedia berupa foto, video, risalah dan putusan. Dari waktu ke waktu, fitur-fitur pada E-Kios ini akan selalu dikembangkan dan disempurnakan sesuai dengan tuntutan keadaan, sehingga diharapkan akan dapat semakin memudahkan masyarakat untuk mengakses informasi yang berhubungan dengan MK. ${ }^{38}$

\subsubsection{Arsip Digital dan E-Minutasi}

Dalam upaya mewujudkan lembaga peradilan yang modern, MK mengelola arsip perkara ke dalam bentuk arsip digital. Seluruh arsip perkara dan produk hukum mulai dari berkas permohonan, jawaban para pihak, alat bukti, risalah persidangan sampai putusan MK dilakukan digitalisasi arsip yang kemudian di upload dalam website MK sebelum nantinya fisik berkas juga di kirim ke arsip nasional sehingga hal tersebut memudahkan pencarian arsip pada saat dibutuhkan kembali.

Selain itu, MK dalam upaya untuk mewujudkan tata kelola arsip digital yang modern juga mengembangkan aplikasi arsip digitalisasi yang menampung semua arsip administrasi umum mulai dari arsip kepegawaian maupun arsip keuangan. Sistem aplikasi yang dibangun ini bernama aplikasi SIPA (Sistem Informasi Pengelolaan Arsip) yang akan memudahkan seluruh pegawai untuk mengelola arsip secara digital..$^{39}$

37 PMK dapat di download di website MK

38 Lihat Laporan Tahunan Mahkamah Konstitusi Tahun 2009, Sekretariat Jenderal dan Kepaniteraan Mahkamah Konstitusi, 2009, hal. 24.

39 Lihat Laporan Tahunan Mahkamah Konstitusi Tahun 2017, Sekretariat Jenderal dan Kepaniteraan Mahkamah Konstitusi, 2017, hal.110. 


\subsubsection{Click Mahkamah Konstitusi}

Dalam upaya untuk mensinkronkan antara website MK dan smartphone, sejak era Sekretaris Jenderal MK ketiga Prof. M. Guntur Hamzah, MK bekerjasama dengan google play store dan apple store membuat aplikasi yang bernama click MK dimana aplikasi ini bertujuan untuk memudahkan masyarakat untuk mengakses persidangan dan perkara Mahkamah Konstitusi melalui smartphone. Dalam aplikasi Click MK ini para pengguna smartphone dapat mengakses putusan, risalah sidang, registrasi online, video streaming sidang, jadwal sidang, dan informasi terkait dengan MK.

Click MK ini menjadi satu-satunya aplikasi ${ }^{40}$ yang berbasis smartphone dimiliki oleh institusi lembaga peradilan di Indonesia. Adanya aplikasi ini sangat diapresiasi oleh masyarakat Indonesia khususnya generasi milenial yang sangat up to date dan selalu menggunakan gadget dalam kesehariannya. Adanya click MK ini menjadi media untuk mensosialisasikan MK melalui teknologi digital yang saat ini menjadi bagian yang tidak terpisahkan dari masyarakat.

\subsection{Penguatan Integrated Judiciary}

Dengan adanya berbagai fasilitas teknologi digital yang digunakan oleh MK untuk mendukung kinerjanya dalam upaya mewujudkan pengadilan yang modern dan terpercaya tentunya juga harus disinergikan dengan lembaga lain khususnya pemerintahan yang mengelola administrasi pemerintahan secara umum.

Hal tersebut dilakukan oleh Mahkamah Konstitusi dengan cara mensinergikan antara e-government dalam peradilan konstitusi (i-judiciary). Adanya berbagai fasilitas teknologi digital yang sudah mendukung MK melalui pengembangan sistem informasi manajemen peradilan konstitusi juga harus disinkronkan dengan berbagai aplikasi lain yang mendukung penerapan e-government yang juga diterapkan di MK. Hal tersebut diwujudkan dengan berbagai program peningkatan kualitas dan kuantitas perangkat Teknologi Informasi dan Komunikasi, pengembangan Sistem Informasi Manajemen Perkantoran e-office dan digitalisasi arsip perkantoran yang kesemuanya bersinergi dengan i-judiciary yang telah dimiliki oleh MK. ${ }^{41}$

\subsection{Penghargaan terhadap MK}

Website MK yang dilaunching pada bulan November 2003 berhasil menjadi website terbaik lembaga negara sehingga mendapatkan penganugerahan e-Transparancy Award 2013 yang digagas oleh Lembaga Paramadina Public Policy Institute (PPPI), Masyarakat Transparansi Indonesia (MTI) dan Unit Kerja Presiden

${ }^{40}$ National Center for State Courts. (2013). The International Framework for Court Excellence. Dikutip dari https://www.courtexcellence.com/_data/assets/pdf_file/0013/7312/the-international-framework2e-2014-v3.pdf

41 Lihat Laporan Tahunan Mahkamah Konstitusi Tahun 2017, Sekretariat Jenderal dan Kepaniteraan Mahkamah Konstitusi, 2017, hal. 62. 
bidang Pengawasan dan Pengendalian Pembangunan (UKP4), yang dalam hal ini membawahi Open Government Indonesia. ${ }^{42}$

\section{Kesimpulan}

Era teknologi digital yang saat ini menjadi bagian dari kemajuan dunia menjadi satu hal yang harus selalu diantisipasi oleh kita semua sebagai masyarakat global. Saat ini melalui teknologi digital semua orang dapat mengakses apapun hanya melalui smartphonenya dan dunia seolah-olah ada dalam genggaman tangan kita. Pesatnya dunia digital saat ini menyebabkan semua pihak harus mau berubah, ikut terlibat, beradaptasi dan berinovasi dengan teknologi.

Pengadilan sebagai salah satu pelayan masyarakat tentunya harus juga dapat menyesuaikan diri mengikuti perkembangan teknologi oleh karena masyarakat yang dilayani oleh pengadilan juga telah menggunakan teknologi. Penggunaan teknologi dalam dunia peradilan menjadi sebuah keharusan agar masyarakat sebagai para pencari keadilan mengalami kemudahan dalam melakukan akses kepada pengadilan.

MK sebagai pengadilan konstitusi yang baru berdiri tahun 2003, namun memiliki misi untuk mewujudkan pengadilan yang modern dan terpercaya serta mewujudkan masyarakat Indonesia yang sadar akan konstitusi dan telah berhasil mewujudkan pengadilan digital (E-Court) yang dapat diakses oleh seluruh masyarakat Indonesia yang berjumlah 260 juta hanya dengan menggunakan smartphone yang mereka miliki dan tanpa mengeluarkan biaya untuk berperkara. Adanya upaya yang serius yang dilakukan oleh MK dengan membuat sistem pengadilan digital (E-Court) telah benar-benar memberikan kemudahan akses bagi masyarakat dalam melakukan berbagai gugatan konstitusional dengan memanfaatkan teknologi digital. Hal tersebut adalah inovasi yang sangat luar biasa yang juga patut ditiru oleh lembaga negara lainya yang ada di Indonesia oleh karena era teknologi digital sudah seharusnya dilakukan secara menyeluruh termasuk menjadi bagian yang tidak terpisahkan dari lembaga pengadilan dalam upaya mewujudkan pengadilan yang bukan hanya ramah terhadap masyarakat tapi juga adil, transparan dan akuntabel sehingga hal tersebut secara otomatis akan meningkatkan kepercayaan masyarakat terhadap lembaga pengadilan.

Semoga MK sebagai satu-satunya lembaga pengadilan penjaga konstitusi, penjaga hak konstitusional warga negara dan penjaga demokrasi dapat terus konsisten menjadi lembaga yang terus berinovasi dengan teknologi dan terus menjaga kepercayaan masyarakat dengan putusan yang adil, berkualitas dan substantif sehingga budaya sadar berkonstitusi dapat tumbuh dengan mudah di negeri yang kita cintai ini.

42 Lihat Laporan Tahunan Mahkamah Konstitusi Tahun 2013, Sekretariat Jenderal dan Kepaniteraan Mahkamah Konstitusi, 2013, hal. 86 


\section{Daftar Pustaka}

Amr. (2003). Pemeriksaan Pendahuluan Mahkamah Konstitusi Dimulai Pekan Depan. hukumonline.com. Dikutip dari https://www.hukumonline.com/berita/baca/hol9037/pemeriksaanpendahuluan-mahkamah-konstitusi-dimulai-pekan-depan

Asshiddiqie, J. (2007). Pembentukan Mahkamah Konstitusi.

Badan Pembina Hukum Nasional. (2017). Rancangan Undang-Undang Kementerian Hukum Dan Hak Asasi Manusia.

Gie. (2004). MK Batalkan Keberlakuan UU Ketenagalistrikan. hukumonline.com. Dikutip dari https://www.hukumonline.com/berita/baca/hol11758/mk-batalkankeberlakuan-uu-ketenagalistrikan

Mahkamah Konsitusi Republik Indonesia. (2003-2017). Laporan Tahunan Mahkamah Konstitusi Tahun 2003 s.d. Tahun 2017, Sekretariat Jenderal dan Kepaniteraan Mahkamah Konstitusi RI.

Mahkamah Konstitusi Republik Indonesia. (2019). Home | The Constitutional Court of the Republic Indonesia. Dikutip dari mkri.id website: https://www.mkri.id/index.php?page=web.Beranda\&menu=1

Malik. (2009). Telaah Makna Hukum Putusan Mahkamah Konstitusi yang Final dan Mengikat. Jurnal Konstitusi, 6(1), 79-104.

National Center for State Courts. (2013). The International Framework for Court Excellence. Dikutip dari https://www.courtexcellence.com/_data/assets/pdf_file/0013/7312/theinternational-framework-2e-2014-v3.pdf

Prasidi, D. (2010). Akses Publik Terhadap Informasi Di Pengadilan. Jurnal Konstitusi, $7(3), 161-184$.

Putri, N. A. (2015). Implikasi Putusan Mahkamah Konstitusi Terkait Dengan Penambahan Norma Penetapan Tersangka Sebagai Objel Praperadilan. Universitas Islam Negeri Syarif Hidayatullah.

Subiyanto, A. (2012). Mendesain Kewenangan Kekuasaan Kehakiman Setelah Perubahan UUD 1945. Jurnal Konstitusi, 9(4), 661-680.

Sumadi, A. (2011). Independensi Mahkamah Konstitusi. Jurnal Konstitusi, 8(5), 631-648.

Sutiyoso, B. (2010). Pembentukan Mahkamah Konstitusi Sebagai Pelaku Kekuasaan Kehakiman Di Indonesia. Jurnal Konstitusi, 7(6), 25-49.

Peraturan Perundang-undangan

Naskah Komprehensif Perubahan UUD 1945 - Buku I s.d. Buku VI, Sekretariat Jenderal dan Kepaniteraan Mahkamah Konstitusi RI. 